\title{
THE ROLE OF INFORMATION LITERACY IN SECONDARY EDUCATION: A TRANSFORMATIVE ELEMENT OF SOCIETY
}

Michal ČERNÝ*, Masarykova univerzita v Brně, Česká republika

Přijato: 26. 4. 2021 / 13. 7. 2021

Typ článku: Teoretická studie

DOI: $10.5507 /$ jtie.2021.009

\begin{abstract}
The overview study works with 19 papers from the Scopus database, which deal with information literacy in secondary schools. It aims to analyse the essential topics and problems that arise in this area and formulate specific recommendations for educational practice. The importance of information literacy for the university's transition to and success was clear from the analysed papers. Information literacy can thus be understood as an influential element in preventing academic failure. At the same time, however, it has a broader social dimension.
\end{abstract}

Key words: information literacy; high school; open educational resources; libraries; librarians; academic skills.

\section{ROLE INFORMAČNÍ GRAMOTNOSTI VE STŘEDOŠKOLSKÉM VZDĚLÁVÁNÍ: TRANSFORMATIVNÍ PRVEK SPOLEČNOSTI}

\begin{abstract}
Abstrakt: Přehledová studie pracuje s 19 texty z databáze Scopus, které se věnují problematice informační gramotnosti na středních školách. Jejím cílem je analýza základních témat a problémů, které se v této oblasti objevují a formulace určitých doporučení do edukační praxe. Z analyzovaných textů jasně vyplynul význam informační gramotnosti pro přechod na univerzitu a úspěch na ní. Informační gramotnost tak Ize chápat jako efektivní prvek předcházení studijní neúspěšnosti. Současně má ale širší sociální rozměr.
\end{abstract}

Klíčová slova: informační gramotnost; střední škola; otevřené vzdělávací zdroje; knihovny; knihovníci; akademické dovednosti. 


\section{1 Úvod}

Téma informační gramotnosti je na jedné straně tématem aktuálním a oblíbeným, na druhé straně složitě uchopitelným. V databázi Scopus pod pojmem „Information literacy“ nalezneme téměř 27 tisíc dokumentů. Od roku 1980 můžeme vidět v podstatě exponenciální růst množství textů, které se této problematiky dotýkají. Nejvíce publikací je spojováno s USA (téměř 11 tisíc dokumentů), následovanou Velkou Británií (2 tisíce dokumentů). Současně jde o téma, které silně zaznívá také ve veřejném prostoru či médiích.

Cílem této přehledové studie bude zachycení diskursu či témat, která se v posledních letech (od roku 2017) objevují ve vztahu mezi informační gramotností a středoškolským prostředím. Jsme si vědomi toho, že pojem „high school“, který používáme při vyhledávání studií, $\mathrm{v}$ různých školních systémech může označovat jiné způsoby vzdělávání nebo jinou věkovou skupinu. Proto v centru našeho zájmu nebudou jednotlivé didaktické postupy nebo výzkumná zjištění, ale spíše sledování obecnějších témat a problémů.



Obr. č. 1: Dokumenty publikované za rok v databázi Scopus při použití pojmu „Information literacy“.

Poprvé pojem informační gramotnost použil Paul Zurkowski v roce 1974 (Aharony, 2010), když tvrdil, že informačně gramotný člověk je ,jedinec připravený použivat informační zdroje při práci, který se při rešení problémů naučil využívat 
širokou škálu technik a informačních nástrojů stejně jako primární zdroje“. (Badke, 2010, s. 48; Zurkowski, 1974, s. 6 ) Tato definice je velice obecná a má silně praktický rozměr - informační gramotnost je schopnost využívat určité postupy, které vedou k zisku informačního zdroje. Zurkowski (vzhledem $\mathrm{k}$ datu uveřejnění definice zcela pochopitelně) pomíjí jeden z podstatných aspektů, o kterém musíme $\mathrm{v}$ kontextu informační gramotnosti hovořit, totiž rozměr digitálních technologií. Jeho chápání je silně spojené s představou, že informace jsou vyhledávané výlučně $\mathrm{v}$ knihovně nebo jiné pamětové instituci.

Podle ALA (American Library Association) je informační gramotnost spojená se schopností se učit. Tato definice z roku 1989 stanovuje jasný a postupně rozvíjející se program spojující schopnost pracovat s informacemi a učit se: „K dosažení informačni gramotnosti musí být jedinec schopen rozeznat, kdy potřebuje určité informace, a dokázat je vyhledat, posoudit a efektivně využít. Informačně gramotní lidé se naučili učit se. Vědí, jak se mají učit, protože vědí, jakým způsobem jsou znalosti pořádány, jak je možné nové informace vyhledat a využit je tak, aby se z nich mohli učit. Informačně gramotní lidé jsou připravení na celoživotní vzdělávání, protože dokážou vždy najít informace potřebné ke svému rozhodnutí či $k$ vyřešení problému."(ALA, 1989; Cheek \& Doskatsch, 1998)

Problémem, který je s informační gramotností didakticky spojený, je, že jde o gramotnost, která se separátně mimo předměty učí poměrně omezeně, byt’ např́klad finské školství právě ke kompetencím silně inklinuje (Kyllönen, 2019, s. 311) a systematicky je implementuje do kurikula, což má za následek erozi předmětného učení. Současně ale platí, že existuje řada studií, které právě informační gramotnost dávají do souvislostí se ziskem tzv. akademických dovedností nebo obecně s úspěchem na vysoké škole (Lanning \& Mallek, 2017; Salisbury \& Karasmanis, 2011). Např́ílad v českém prostředí se lze říci, že informační gramotnost jistě lze učit i v rámci dalších předmětů, výzkum (Černý, 2019) ukázal, že samy školy o takovýto prrístup usilují, byt výsledky nejsou zcela přesvědčivé z hlediska dopadu na skutečné dovednosti studentů (ČŠI, 2018).

Jakkoli existuje mnoho modelů či kompetenčních rámců spojených s informační gramotností SCONUL (Bent, M., \& Stubbings, 2011), BIG6 (Eisenberg \& Berkowitz, 1999), MIL (Grizzle et al, 2014; Moeller et al. 2011), AASL (Burns et al. 2019; Farmer, 2013), ACRL (Emmett \& Emde, 2007; Catalano, 2010) a další, které se uplatňují v návrzích edukačních aktivit či v online kurzech, výzkumný diskurs s nimi pracuje relativně málo. Možná o tom více se zaměřuje na obecnější otázky a problémy, které s informační gramotností souvisí. 
Výzkumnou otázku tedy můžeme explikovat následovně: „Jaký je současný výzkumný a publikační diskurs v oblasti informační gramotnosti v prostř̌edí středních škol?". Ve studii proto identifikujeme důležitá témata a problémy, které se v této oblasti v aktuální literatuře reflektují.

\section{Metodologie}

Pro přehledovou studii (Mareš, 2013) jsme zvolili databází Scopus. Nebot bylo našim cílem postihnout současná témata a prŕstupy, které jsou s informační gramotností spojená, rozhodli jsme se, že výsledky vyhledávání omezíme na roky 2017-2021. Toto omezení tedy zajištuje aktuálnost zdrojů. Některé studie pracují s delšími časovými obdobími (Nzomo \& Fehrmann, 2020; Pashkova-Balkenhol et al., 2019), ale takový postup by pro nás byl irelevantní. Výsledky jsme omezily na ty, ke kterým bylo možné bezplatně přistupovat, tedy byly publikovány pod nějakou formou Open Access licence.

Nebot’ se zaměřujeme na téma informačního vzdělávání na stř̌edních školách užili jsme pro vyhledávání v databází fráze "Information literacy" a "high school" (bylo by možné uvažovat o širším souboru dat, získaném například přidáním alternace "secondary school", ale zda bychom naráželi na problém ještě větší různorodosti textů pracujících s jinými vzdělávacími systémy; současně korpus 19 výsledných textů je pro přehledovou studii tohoto druhu dostatečný). Tato dvě klíčová slova (spojení slov) dokázala poměrně dobře vyselektovat jednotlivé texty. Tím, že se soustředíme na problematiku související se vzděláváním, jsme užili ještě filtrů na sociální a humanitní věty. Po užití těchto filtračních kritérií nebylo nalezeném souboru se nenacházen žádný dokument, který by bylo nutné hodnotit jako irelevantní k tématu našeho výzkumu. Nalezených 23 studí současně představoval soubor dostatečně velký na to, aby bylo možné vytvořit přehledovou studii a současně vhodně rozsáhlý z hlediska možného zpracování dat (výsledek nebyl př́liš široký).

Výsledný vyhledávaný dotaz ve Scopus měl tedy následující podobu:

TITLE-ABS-KEY ( "Information literacy" "high school") AND ( LIMIT-

TO ( OA, "all")) AND ( LIMIT-TO ( PUBYEAR, 2021 ) OR LIMIT-

TO ( PUBYEAR, 2020 ) OR LIMIT-TO ( PUBYEAR, 2019 ) OR LIMIT-

TO ( PUBYEAR, 2018 ) OR LIMIT-TO ( PUBYEAR, 2017 ) ) AND ( LIMIT-

TO ( SUBJAREA, "SOCI" ) OR LIMIT-TO ( SUBJAREA, "ARTS" ) ) 
Vyhledávání bylo provedeno 14. 3. 2021, což je datum, ke kterému můžeme garantovat dostupnost jednotlivých textů. Databáze Scopus byla vybrána jako jedna ze dvou (spolu s WoS), která provádí náročný výběr zdrojů, které v ní mohou být uvedeny. Jde tedy o určitý parametr výzkumné kvality.

Jako dodatečné kritérium jsme zvolili dostupnost textů $\mathrm{v}$ angličtině. $\mathrm{Z}$ tohoto důvodu jsme museli vyřadit studie v ruštině (Svirina, 2020), chorvatštině (Vitorii et al., 2018), turečtině (Şenyurt \& Önal, 2019) a španělštině (García Llorente et al., 2019).

Námi prováděná přehledová studie má primárně kvalitativní charakter (Mareš, 2013). Našim cílem je identifikace klíčových výzkumných témat (Galvan, 2006; Randolph, 2009; Hart, 2005). Usilujeme tedy o vytvoření jasné struktury současného diskursu vědeckého bádání a identifikace důležitých témat (Mayer, 2009) v oblasti informační gramotnosti, který by mohl být odrazovým můstkem pro další vědecké zkoumání. Dle Marešovy (2013) typologie jde o přehledovou studii tradiční narativní (Rozas \& Klein. 2010; Needleman, 2002).

\section{Výsledky}

V rámci našeho výzkumu jsme získali celkem 23 odpovídajících záznamů v databázi Scopus, $4 \mathrm{z}$ nich jsme museli vyřadit, nebot nebyly v anglickém jazyce. Zbývajících 19 je uvedených v následující tabulce. Pokud jde o státy, ze kterých studie pocházejí, tak nejhojněji jsou zastoupené Spojené státy americké (8), následované Vietnamem (2 - obě od stejných autorů), Thajsko (2) a Japonskem (2). Z dalších zemí je př́tomné Portugalsko, Turecko, Malajsie, Velká Británie, France, Dánsko, Austrálie a Jihoafrická republika.

V tabulce uvádíme také počet citačních ohlasů evidovaných v databázi Scopus, který je v rozptylu mezi 0 a 12 citačními ohlasy. Průměr je 2,8 , byt jde o číslo zavádějící, a to především s ohledem na skutečnost, že studie z let 2020-2021 neměly „dostatek času“ citační ohlasy získat. Všechny analyzované texty měly DOI a bylo možné se dostat $\mathrm{k}$ jejich plným textům, což odpovídá metodologii výběru jednotlivých studií. 


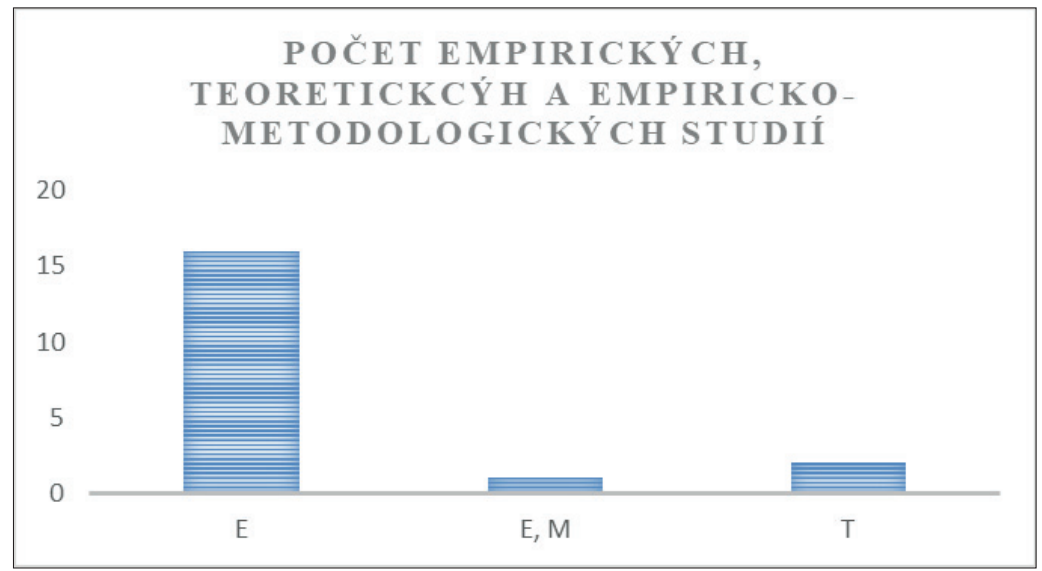

Graf č. 1: Graf zachycuje typologické členění studií z námi studovaného souboru. Je patrné jasné prevládání empiricky orientovaných textů pred teoretickými, případně metodologickými.

E - empirická studie, T - teoretická studie, E, M - empiricko-metodologická studie.

\section{DRUHY VÝZKUMNÝCH DESIGNŮ}

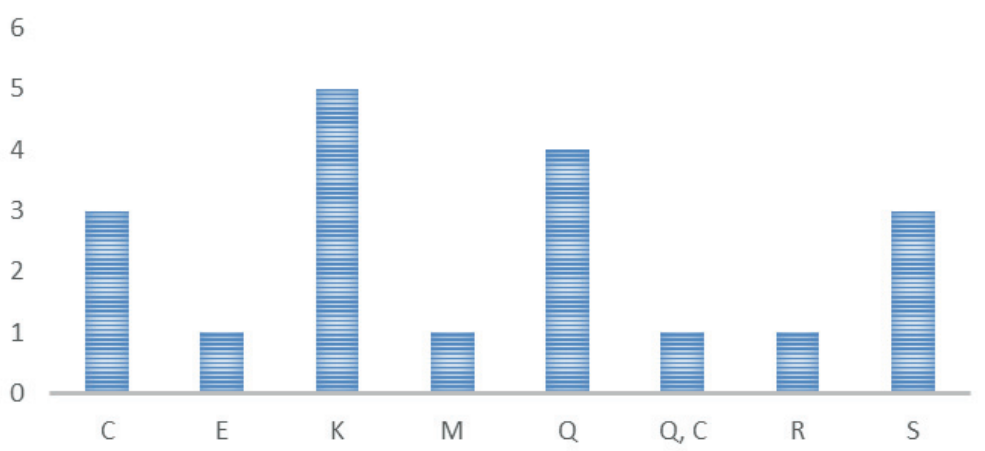

Graf č. 2: zachycuje základní výzkumné designy v analyzovaných textech.

K - kvalitativní výzkum, $R$ - přehledová studie, $Q$ - kvantitativní výzkum, C - prípadová studie, $M$ metastudie, S - smíšený výzkumný design, E - evaluace výzkumného nástroje. Převládají kvalitativní, kvantitativní a smíšené výzkumné designy. 
Řazení položek v tabulce je chronologické. U studií od Ngo a kol. je užito pro odlišení let označení 2019 a 2019a. Rok označuje rok vydání, Druh rozlišuje mezi teoretickým ( $\mathrm{T}$ ) a empirickým (E) článkem (případně metodologickým - M). Grafické rozložené zachycuje graf č. 1. Klíčové sdělení je stručným souhrnem vztaženým k námi analyzovanému tématu, Cit. označuje citační ohlasy, které jsou počítány ze Scopus, Nástroj zachycuje základní pohled na metodologické nástroje či postupy a Stát označuje území, na kterém došlo k výzkumnému šetření. V tabulce pracujeme se zkratkou IL pro informační gramotnost.

Výzkumné designy (Des.) jsou v tabulce č. 1 označené zkratkami: $\mathrm{K}$ - kvalitativní výzkum, $\mathrm{R}$ - přehledová studie, $\mathrm{Q}$ - kvantitativní výzkum, $\mathrm{C}$ - případová studie, $\mathrm{M}$ - metastudie, $\mathrm{S}$ - smíšený výzkumný design, E - evaluace výzkumného nástroje. Jejich grafické rozložení zachycuje graf č. 2 .

Tab. č. 1: Tabulka s jednotlivými analyzovanými texty z databáze SCOPUS.

\begin{tabular}{|c|c|c|c|c|c|c|}
\hline Název & Rok & $\begin{array}{l}\text { Druh } \\
\text { D }\end{array}$ & Klíčové sdělení & Stát & Des. & Cit. \\
\hline $\begin{array}{l}\text { Transitioning to college: } \\
\text { Impact of high school } \\
\text { librarians }\end{array}$ & 2021 & E & $\begin{array}{l}\text { Prítomnost knihovníka (alespoň na poloviční úvazek) } \\
\text { na střední škole významně koreluje s úspěch studentů } \\
\text { v prvních ročnících univerzit. IL je kličcovým předpokladem } \\
\text { pro úspěch v akademickém prostředí. Výzkum byl realizo- } \\
\text { ván na vzorku asi } 23 \text { tisíc studentů v Kalifornii. }\end{array}$ & USA & 0 & 0 \\
\hline $\begin{array}{l}\text { Advocacy engagement: The } \\
\text { role of information literacy } \\
\text { skills }\end{array}$ & 2020 & $\mathrm{~T}$ & $\begin{array}{l}\text { Existuje silný vztah mezi znalostmi, dovednostmi a postoji } \\
\text { a mezi ll. Ukazuje se, že rozvoj informační gramotnosti je } \\
\text { důležitý pro efektivní studium v různých oborech lidské } \\
\text { činnosti a umožňuje dobré uplatnění jako v oblasti aka- } \\
\text { demického, tak osobního života. Výzkum také potvrzuje } \\
\text { vhodnost zapojení knihovníků do procesu edukace. }\end{array}$ & USA & R & 0 \\
\hline $\begin{array}{l}\text { Digital participation and } \\
\text { risk contexts in journalism } \\
\text { education }\end{array}$ & 2020 & $E$ & $\begin{array}{l}\text { Článek se zaměruje na téma vzdělávání budoucích noviná- } \\
\text { rơ a jejich edukaci tématizuje mj. i prostřednictvím infor- } \\
\text { mační gramotnosti, která je pro práci novináře zásadní. }\end{array}$ & POR & C & 1 \\
\hline $\begin{array}{l}\text { Should we flip the script?: } \\
\text { A literature review of } \\
\text { deficit-based perspectives } \\
\text { on first-year undergraduate } \\
\text { students' information literacy }\end{array}$ & 2019 & $\mathrm{~T}$ & $\begin{array}{l}\text { Rozsáhlá studie upozorňuje na skutečnost, že výzkumný } \\
\text { diskurs v oblasti Il a skutečností nemusí být v souladu. } \\
\text { Chybí nám totiž data o potřebách samotných studentů, } \\
\text { která jsou nahrazována testy a rámci s deklarativním } \\
\text { přistupem. Ukazuje se, že přechod mezi stupni vzdělávání } \\
\text { (střední škola - univerzita) je velice náročný a vy̌̌aduje } \\
\text { změněnou strukturu IL. Je nutné se obrátit ke konstruktivi- } \\
\text { stickému přistupu a pracovat s potřebami studentů, nikoliv } \\
\text { s normativně určenými kompetencemi. }\end{array}$ & USA & M & 1 \\
\hline
\end{tabular}




\begin{tabular}{|c|c|c|c|c|c|c|}
\hline Název & Rok & Druh & KKlíčové sdělení & Stát & $\begin{array}{l}\text { Des. } \\
\text { Des }\end{array}$ & Cit. \\
\hline $\begin{array}{l}\text { What High School Students } \\
\text { Want to Know about Music: } \\
\text { An Information Literacy } \\
\text { Instruction Course for a High } \\
\text { School Music Camp }\end{array}$ & 2019 & $\mathrm{E}$ & $\begin{array}{l}\text { Článek vychází ze zkušenosti s rozvojem IL u studentů hud- } \\
\text { by, ale má obecněǰ́i sdělení - letní kurzy, tábory, krátké } \\
\text { intenzivní několikadenní semináře, jsou studenty dobře } \\
\text { príijaty a mohou mít velký vliv na úroveň jejich IL. }\end{array}$ & USA & $C$ & 0 \\
\hline $\begin{array}{l}\text { Information literacy capa- } \\
\text { bilities of upper secondary } \\
\text { students: the case of Vietnam }\end{array}$ & 2019 & $\mathrm{E}$ & $\begin{array}{l}\text { Studie ukazuje, že studenti středních škol ve Vietnamu } \\
\text { nemají dobrou úroveň IL a že svoji úroveň významně } \\
\text { nadhodnocují. Nejhưre jsou na tom v oblasti hodnocení } \\
\text { informačních zdrojů a vyhledávacích strategiích. Studie } \\
\text { zdůrazňuje, že povrchní znalost použivání Google nevede } \\
\text { k plně rozvinuté schopnosti nacházet informace. }\end{array}$ & VSR & 0 & 4 \\
\hline $\begin{array}{l}\text { An information literacy } \\
\text { teaching model for Vietnam's } \\
\text { schools }\end{array}$ & $2019 a$ & $\mathrm{E}$ & $\begin{array}{l}\text { Článek na základě rozhovorů tvoří konstruktivistický model } \\
\text { vzdělávání, který je založený na rámci AASL. Akcentuje } \\
\text { nutnost systematického rozvoje IL a nutnost zapojení } \\
\text { více aktérů vzdělávánís ohledem na konkrétní vzdělávací } \\
\text { prostředí. }\end{array}$ & VSR & $0, C$ & 0 \\
\hline $\begin{array}{l}\text { A pilot project to increase } \\
\text { health literacy among youth } \\
\text { from seasonal farmworker } \\
\text { families in rural eastern } \\
\text { North Carolina: A qualitative } \\
\text { exploration of implementati- } \\
\text { on and impact }\end{array}$ & 2019 & $E$ & $\begin{array}{l}\text { Studie uvádí, že rozvoj IL může být (především u osob s niž- } \\
\text { śím sociálním kapitálem) transformativní, vede k lepšímu } \\
\text { zájmu a k přístupu ke svému zdraví, ke rozvoji schopnosti } \\
\text { hodnotit zdroje a díky tomu se lépe rozhodovat. Pro sociál- } \\
\text { ní spravedlnost je nezbytný rovný přístup k internetu. }\end{array}$ & USA & K & 2 \\
\hline $\begin{array}{l}\text { The information technology } \\
\text { literacy level of newly enro- } \\
\text { lled female college students } \\
\text { in Japan }\end{array}$ & 2019 & $\mathrm{E}$ & $\begin{array}{l}\text { Studie se zaměřuje více na schopnost práce s kancelářským } \\
\text { balíkem než na vlastní informační gramotnost, ale přesto } \\
\text { odkazuje k důležitému zjištění - expertní úrovně se } \\
\text { dostává těm, co se učí především doma, nikoliv v rámci } \\
\text { formálního vzdělávání ve škole. Strategie rozvoje IL musí } \\
\text { být podle autorů soustředěná nikoliv jen na školní kuriku- } \\
\text { lum, ale především na podporu rodin. }\end{array}$ & JAP & $Q$ & 2 \\
\hline $\begin{array}{l}\text { eHealth literacy of high } \\
\text { school students in the } \\
\text { Philippines }\end{array}$ & 2019 & $\mathrm{E}$ & $\begin{array}{l}\text { Článek dává do souvislostí zdravotní a informační gra- } \\
\text { motnost. Ukazuje, že studenti jsou poměrně silní v oblasti } \\
\text { vyhledávání informací, ale již méně v jejich hodnocení } \\
\text { a využívání, což představuje vážný problém. }\end{array}$ & PHL & Q & 1 \\
\hline $\begin{array}{l}\text { Information needs and } \\
\text { constraints of access to } \\
\text { educational information in } \\
\text { the fort beaufort education } \\
\text { district }\end{array}$ & 2019 & $\mathrm{E}$ & $\begin{array}{l}\text { Přístup k informacím a informační gramotnost nejsou } \\
\text { podle této studie pouze předpokladem pro akademické } \\
\text { studium, ale nezbytným parametrem demokratické } \\
\text { a svobodné společnosti. Nedostupnost informacínebo } \\
\text { špatná práce knihovníků vede k nespravedlivé společnosti. } \\
\text { Je ť̌eba hledat nástroje, jak studentům zajistit prístup } \\
\text { k informacím, které potřebují - od výběru školy, požadav- } \\
\text { ků na př́íímací řizení až třeba po sexuální výchovu. }\end{array}$ & JAR & $S$ & 0 \\
\hline
\end{tabular}




\begin{tabular}{|c|c|c|c|c|c|c|}
\hline Název & Rok & $\begin{array}{l}\text { Druh } \\
\text { D }\end{array}$ & KKlíčové sdělení & Stát & $\begin{array}{l}\text { Des. } \\
\text { Des }\end{array}$ & Cit. \\
\hline $\begin{array}{l}\text { The Role of the University } \\
\text { Library in Supporting Inter- } \\
\text { national Student Transition: } \\
\text { Insights From an Australian- } \\
\text {-American Case Study }\end{array}$ & 2018 & $\mathrm{E}$ & $\begin{array}{l}\text { Knihovna hraje dủležitou roli v procesu podpory mezi- } \\
\text { národních studentů. Studijní potřeby studentů z jiných } \\
\text { kulturních prostředí jsou podobné, jako studentů } 1 . \\
\text { ročníků, což umožňuje dobrou adaptaci edukačních progra- } \\
\text { mů a služeb pro tuto cílovou skupinu. Podpora rozvoje IL } \\
\text { obecně hraje kličovou roli v úspěšném studiu. }\end{array}$ & $\begin{array}{l}\text { USA- } \\
\text { AUS }\end{array}$ & $S$ & 8 \\
\hline $\begin{array}{l}\text { Adaptation, translation, and } \\
\text { validation of information } \\
\text { literacy assessment instru- } \\
\text { ment }\end{array}$ & 2018 & $\mathrm{E}, \mathrm{M}$ & $\begin{array}{l}\text { Článek se věnuje problematice lokalizace, adaptace } \\
\text { a standardizace měření úrovně IL pomocí testu TRAILS-9. } \\
\text { Zdůrazňuje, že informace o IL máme téměř výhradě } \\
\text { z okcidentálního kulturního okruhu, a to včetně metodolo- } \\
\text { gických a kompetenčních prístupů. }\end{array}$ & MYS & $\mathrm{E}$ & 2 \\
\hline $\begin{array}{l}\text { Are social networking } \\
\text { sites information sources? } \\
\text { Informational purposes of } \\
\text { high-school students in } \\
\text { using SNSs }\end{array}$ & 2018 & $\mathrm{E}$ & $\begin{array}{l}\text { Studie sledovala využívání sociálních médií jako zdrojü } \\
\text { informací. Asi pětina studentů takto o tomto druhu služeb } \\
\text { nepřemýšlí, ale stejná část je využíá pro vyhledávání } \\
\text { informací o škole, vzdělávání nebo školních projektech. } \\
\text { Ukazuje se, že role IL ve vztahu k sociálním médím je zá- } \\
\text { sadní, vzhledem k tomu, že většina studentů tyto nástroje } \\
\text { používá na denní bázi. }\end{array}$ & $\begin{array}{l}\text { GB } \\
\text { FR } \\
\text { DK }\end{array}$ & K & 12 \\
\hline $\begin{array}{l:}\text { A Thai junior high school } \\
\text { students' 21st century } \\
\text { information literacy, media } \\
\text { literacy, and ICT literacy skills } \\
\text { factor analysis }\end{array}$ & 2018 & $\mathrm{E}$ & $\begin{array}{l}\text { Studie hodnotila gramotnost thajských středoškolákủ } \\
\text { voblasti počítačové, mediální a IL. Výzkum je zajímavý } \\
\text { tím, že pro každou oblast definoval kompetence, které byly } \\
\text { analyzované v rámci dotazníku. }\end{array}$ & THA & K & 6 \\
\hline $\begin{array}{l}\text { An investigation of the social } \\
\text { network system competen- } \\
\text { cies of high school students } \\
\text { in Japan }\end{array}$ & 2018 & $\mathrm{E}$ & $\begin{array}{l}\text { Studie provádí analýzu kompetencí pro práci se sociálními } \\
\text { sítěmi u studentů. V některých položkách Ize vidět těsný } \\
\text { vztah k IL (využivá se rámec MIL). Z výzkumu plyne, že } \\
\text { studenti v Japonsku jsou schopni efektivně sociální média } \\
\text { využivat. }\end{array}$ & JAP & K & 3 \\
\hline $\begin{array}{l}\text { Aligning the Curriculums } \\
\text { for College Success: High } \\
\text { School and College Library } \\
\text { Collaborations }\end{array}$ & 2017 & $\mathrm{E}$ & $\begin{array}{l}\text { Studie upozorňuje, že existuje silná disproporce mezi IL } \\
\text { středoškoláků a požadavky univerzity. IL je předpokladem } \\
\text { pro akademické studium a její absence je pro studenty } \\
\text { velkou přítěží. Za zvláště problematickou hodnotí studie } \\
\text { situaci v oblasti kritického myšlení. Za cestu je považováno } \\
\text { rozšírení výuky (časové dotace), kvalitní spolupráce učitelů } \\
\text { a knihovníkủ. }\end{array}$ & USA & $S$ & 0 \\
\hline $\begin{array}{l}\text { Proposal of a framework for } \\
\text { the assessment of ICT literacy } \\
\text { and examining the structure } \\
\text { of high school students' ICT } \\
\text { literacy: A case of Turkey }\end{array}$ & 2017 & $\mathrm{E}$ & $\begin{array}{l}\text { Studie tvrdí, že existují velké rozdíly v úrovni IL, a to } \\
\text { i přesto, že školství v Turecku je poměrně standardizo- } \\
\text { vané. Z toho vyplývá skutečnost, že práce s osnovami } \\
\text { a doporučenými postupy je nedostatečná. Dlouhodobé } \\
\text { rozdíly v úrovni IL v vedné oblasti mohou vést k závažným } \\
\text { problémům. }\end{array}$ & TUR & K & 0 \\
\hline
\end{tabular}




\begin{tabular}{|c|c|c|c|c|c|c|}
\hline Název & Rok & Druh & KKlíčové sdělení & Stát & $\begin{array}{l}\text { Des. } \\
\text { D. }\end{array}$ & Cit. \\
\hline $\begin{array}{l}\text { Your teaching strategy } \\
\text { matters: How engagement } \\
\text { impacts application in } \\
\text { health information literacy } \\
\text { instruction }\end{array}$ & 2017 & $\mathrm{E}$ & $\begin{array}{l}\text { Článek zdůrazňuje význam aktivního učení v oblasti lL. } \\
\text { Ukazuje se, že transmisivní metody jsou neefektivní } \\
\text { a je třeba pracovat s konstruktivistickým paradigmatem } \\
\text { akcentujíím aktivní učení, zkoušení si postupů a vlastní } \\
\text { experimentování. Knihovny by měly tuto praxi vhodným } \\
\text { způsobem podporovat. }\end{array}$ & USA & C & 12 \\
\hline
\end{tabular}

\section{Analýza}

Společným tématem několika studií je vztah informační gramotnosti a akademické úspěšnosti. Ukazuje se, že bez dobrého vzdělání v této oblasti může být přechod mezi jednotlivými stupni vzdělávání velice problematický (Andrews \& Saint Hilaire, 2017; Farmer \& Phamle, 2021). Nedostatečně rozvinutá úroveň informační gramotnosti tedy představuje jednu $\mathrm{z}$ bariér při přechodu mezi sekundárním a terciálním stupněm vzdělávání, které bychom měli věnovat dostatečnou pozornost. Informační vzdělávání tedy není jen fakultativní aditivní složkou kurikula, ale ukazuje se, že představuje základní kompetenci k učení a akademické práci.

Otázkou, která v současné době zůstává nezodpovězená je přitom role studenta $\mathrm{v}$ procesu vzdělávání. $\mathrm{V}$ podstatě všechny texty, které se tématu explicitně věnují zdůrazňují konstruktivistický rozměr vzdělávání (Pashkova-Balkenhol et al., 2019; Ngo et al., 2019a; Johnson \& Barrett, 2017; Duffy, 2019). A to jak z hlediska metod výuky, tak především důrazem na aktuální edukační situaci studenta, kterou by edukační aktivity spojené s informačním vzděláváním měly saturovat. Přitom existují studie, které ukazují, že sebehodnocení studentů nemusí být ideálním evaluačním nástrojem (Ngo et al., 2019).

Informační vzdělávání má velký vliv na spravedlivý př́istup ke vzdělávání, k informacím a obecně k pěstování funkční a demokratické společnosti. Toto téma silně akcentuje Oyediran-Tidings et al. (2019), kteří zdůrazňují, že bez informační gramotnosti nelze myslet funkční spravedlivou společnost. Pokud jsme v úvodní poznámce akcentovali akademický význam informační gramotnosti, zde můžeme zmínit rozměr humanitární. Nerovnoměrnost nebo nedostatečnost (Soysal et al. 2017) informační gramotnosti proto vede k velkým sociálním problémům.

Rozvinutá informační gramotnost představuje cestu jak k úspěšnému fungování v běžné životě (Aillerie \& McNicol, 2018; Yosida, 2018), tak v oblasti pracovní (Nzomo \& Fehrmann, 2020). Odráží se ale také na schopnosti reflektovat a vyhodnocovat informace týkající se zdraví (Camiling, 2019; Mendez et al., 2019). 
V tomto ohledu opět můžeme říct, že rozvoj informační gramotnosti by mělo představovat klíčové téma $\mathrm{v}$ oblasti sociálně pedagogické politiky jednotlivých států. Vážné problémy mají totiž především ti, kteří disponují nižším sociálním a kulturním kapitálem (Mendez et al., 2019).

Texty hojně zdůrazňují roli knihoven a knihovníků v procesu informačního vzdělávání, a to napřič kontexty a situacemi, ve kterých probíhal výzkum (Oyediran-Tidings et al. 2019; Hughes et al., 2018; Andrews \& Saint Hilaire, 2017; Johnson \& Barrett, 2017). Zdá se, že faktické prolínání informačního vzdělávání jako fenoménu školního i knihovního je ve výzkumném diskursu silným a nosným tématem. Je přitom zajímavé, že se v podstatě nesetkáváme se modelem konkurence, ale výhradně s formou akcentující kolaboraci, což lze vnímat jako silně pozitivní signál. Ngo et al. (2019a) se domnívají, že právě jejich spolupráce musí být silně kotvena v konkrétním společenském prostředí. Problematičnost reálné implementace ale ukazuje např́klad Nishikawa a Izuta (2019), kteří akcentují, že pro informační vzdělávání je zásadní vliv domácího prostř̌edí, zvláště při přechodu na expertní úroveň. Tím se opět dostáváme ke vztahu informační gramotnosti a edukačních možností v akademickém prostředí. Vyšší sociální a kulturní kapitál ovlivňuje nejen schopnost úspěšně studovat, ale i samotnou informační gramotnost.

Samotné téma informační gramotnosti není často analyzované či rozvíjené samostatně, ale můžeme se s ním setkat v různých kontextech, jako je vzdělávání v konkrétních profesích (Dzula et al., 2020) nebo ve spojení s digitálními nebo mediálními kompetencemi (Nishikawa \& Izuta, 2019; Moto et al., 2018; Yoshida, 2018). To ukazuje, že nestojí zcela mimo společenský koncept, ale že se vztahuje do mnoha dimensí lidského chování. Pobyt v informační společnosti a informační gramotnost od sebe není možné oddělovat (Oyediran-Tidings et al., 2019).

Pokud jde o výzkumné metody, Hani Syazillah et al. (2018) zdůrazňují význam adaptace testů, pokud chceme mít možnost porovnávat jednotlivé výsledky. Články, které jsme mohli analyzovat ukazují, že taková standardizace jistě nepředstavuje dominantní výzkumný diskurs, lze spiše sledovat kvalitativní i kvantitativní výzkumy, odpovídající na konkrétní výzkumné otázky jednotlivých autorů. Větší oblibě se těší výzkum kvantitativní (především dotazníky a testy), před smíšenými a kvalitativními metodami (rozhovory) a př́padovými studiemi. V podstatě chybí studie čistě teoretické.

$\mathrm{Z}$ námi analyzovaných textů můžeme formulovat následující doporučení: 
- Kompetence v oblasti informační gramotnosti korelují se schopností studentů zvládat vysokou školu, především pak uspět v prvních ročnících. Jeví se proto jako zásadní se na toto téma na středních školách soustředit, především pokud mají akademický profil studia. Informační gramotnost tak lze chápat jako efektivní prvek předcházení studijní neúspěšnosti.

- Informační gramotnost má vliv na schopnost jedince participovat na občanské společnosti, ale také se svobodně rozhodovat, být úspěšný v práci nebo $\mathrm{v}$ řešení problémů. Zdá se jako klíčové hledat cesty, jak informační gramotnost rozvíjet u osob sociálně znevýhodněných. Jde o nástroj sociálně inklusivní politiky.

- Zásadními tématy v oblasti informační gramotnosti je schopnost kritické práce se zdroji, kritické myšlení a schopnost hodnotit informace.

- Př́tomnost knihovníka (nejméně na poloviční úvazek) na střední škole představuje edukačně i sociálně pozitivní moment, může být součástí inklusivních a sociálních politik státu.

- Je nutné hledat cesty, jak přibližit informační vzdělávání na středních školách a na univerzitách. Studie ukazují, že mezi oběma prostředími panuje určitá disproporce, která studentům ztěžuje přechod mezi stupni studia.

- V oblasti informačního vzdělávání je kladen velký důraz na konstruktivistické pojetí edukace. Zdá se, že výběr jedné formy nebo způsobu není podstatný, ale klíčové je hledat postupy, které povedou k tomu, že se studenti budou učit tomu co potřebují, tehdy kdy to potřebují aktivním způsobem.

- Informační vzdělávání by mělo být společným projektem škol a knihoven. Měli bychom ale být schopni uvažovat i o jeho širších dimensích $s$ ohledem na situaci v rodině, na trhu práce nebo na konkrétních lokálních podmínkách.

\section{Diskuse}

Odborná literatura se silně soustředí na téma přechodu mezi jednotlivými stupni vzdělávání. Jde obecně o velkou osobní a životní změnu (Maunder et al., 2013). Proto je nezbytné, aby na tuto situaci reagovaly také univerzity a hledaly cesty k podpoře studentů, kteří se ve vysokoškolském prostředí mohou cítit ztraceni. Svět infomačních potřeb je totiž radikálně odlišný (Salisbury \& Karasmanis, 2011; Lwehabura, 2018; Schofield, 2012; Farmer, 2015; Lanning \& Mallek, 2017), takže zatímco na střední škole se informační gramotnost silně zaměřuje na oblast médií a sociálních sítí v kontextu vysoké školy lze vidět důraz na odborné zdroje a vědecké časopisy, práce s databázemi a především na náročnější operace jako 
jsou pokročilé vyhledávací strategie schopnost pracovat s daty a kriticky hodnotit jednotlivé texty (Donham, 2014; Head, 2013).

Zatímco Candy (2004) se domníval, že je možné pracovat s různou úrovní informační gramotnost, jako s něčím přirozeným, protože jde o kompetenci stejnou, jako mnoho dalších, zdá se, že výzkumný diskurs je v tomto ohledu velice odlišný. Naopak se zdá být pravděpodobné, že existuje silný vztah mezi kompetencí k učení a informační gramotnosti (Candy 2004; Candy, 2002; Turusheva, 2009; Uzunboylu \& Hürsen, 2011; Dolničar et al., 2020).

I z námi analyzovaných textů vyplynulo, že právě přechod mezi stupni vzdělávání je mimořádně náročný a pro jeho efektivní zvládnutí by bylo vhodné hledat aktivní komunikaci mezi akademickými a středoškolskými knihovníky (Carr \& Rockman, 2003; Donham \& Rehmke, 2016; Foote, 2016). Výzkumy poměrně jednoznačně ukazují, že existuje spojitost (tu dokládají také námi analyzované texty) mezi akademickým úspěchem a informační gramotností (Fitzgerald, 2004; Head, 2013; Lanning \& Mallek, 2017; Salisbury \& Karasmanis, 2011), a že v právě knihovníci mohou v oblasti informační edukace hrát významnou roli (Brown \& Malenfant, 2017; Gaha et al., 2018).

Výzkum informačních potřeb studentů středních škol v Nigerii zaznamenal, že primární potřeby studentů souvisí s jejich studiem (Adesoye \& Amusa, 2011; Akinola et al., 2013), ale jak uvádí Udofia (2012), má těsnou souvislost také s kulturním prostředím či rodinným zázemím, což potvrzují i ze zcela jiného kulturního prostředí Nishikawa a Izuta (2019). Jinými slovy, školní prostředí, kulturní život a běžné lidské či občanské prostředí od sebe nemůžeme oddělit ani v abstraktním analytickém nahlédnutí. V informačním gramotnosti jde o potřeby celého člověka; zasahující jak do studentské dimense, tak do oblasti sociálních vazeb a identity, psychologické či volnočasové sféry.

Ribot a Peluso (2003), stejně jako Oyediran-Tidings et al. (2019), zdůrazňují právo na informace jako základní právo vztažené ke spravedlivému vzdělávání (Saunders, 2017; Webber \& Johnston, 2017). Toto právo nemůže být zajištěno jen de jure, ale pro svoji realizaci de facto, vyžaduje jistou míru informační gramotnosti. Jarvis $(2007,2009)$ zdůrazňuje roli informační gramotnosti jako prvku zachovávajícího svobodu v informační společnosti, která je informacemi přeplněná. $\mathrm{Na}$ jednu stranu tedy potřebuje svobodný a otevřený př́stup, na stranu druhou schopnost s informacemi adekvátně nakládat.

V této oblasti se téma informační gramotnosti potkává s širšími úvahami o významu otevřeného prŕstupu k informačním zdrojům (North et al., 2009; Herb, 
2010; Docherty, 2004). Zdá se, že právě rozvoj konkrétních kompetencí spojených s informační gramotností vytvárí prostor pro budování nové, hlouběji a demokratičtěji chápané informační společnosti (Dutton, 2004; Nath, 2017).

\section{Závěr}

Cílem této přehledové studie bylo identifikovat témata, které se v oblasti informační gramotnosti objevují. Za zásadní společný jmenovatel lze bezpochyby jmenovat určitý sociální rozměr této gramotnosti. Rozvoj informační gramotnosti představuje cestu ke společnosti, ve které se studenti dokáží lépe a efektivněji vzdělávat, budou schopnosti se do ní lépe integrovat a současně budou participovat na společenských procesech v ní. V tomto ohledu se domníváme, že přes exponenciální růst studií, který jsme pojmenovávali v úvodu naší studie, jde o téma zatím nedostatečně prakticky uchopené a akcentované. Především pro osoby ze sociálně znevýhodněného prostředí může představit bariéru nebo hendikep ve výběru školy, ve schopnosti na ní uspět, ale i v procesu celoživotního vzdělávání, což může mít sociálně mimořádně vážné následky.

\section{Poděkování}

Studie byla provedena v rámci řešení projektu Platforma pro transfer znalostí: informační gramotnost pro středoškoláky v otevřeném mash-up virtuálním učebním prostředí (TL02000040) podpořeného TA ČR v rámci projektového schématu Éta 2.

\section{Literatura}

Adesoye, A. E., \& Amusa, O. I. (2011). Investigating the information needs of sandwich and parttime students of two public universities in Ogun State, Nigeria. Library Philosophy and Practice, 1.

Aharony, N. (2010). Information literacy in the professional literature: An exploratory analysis. Aslib Proceedings.

Aillerie, K., \& McNicol, S. (2018). Are social networking sites information sources? Informational purposes of high-school students in using SNSs. Journal of Librarianship and Information Science, 50(1), 103-114. Doi: 10.1177/0961000616631612

Akinola, J. O., Apotiade, J. K., Ogunmodede, T. A., \& Oyetola, S. O. (2013). A survey of the services of public libraries in meeting the information needs of postsecondary school students in some three selected public libraries in Nigeria. Greener Journal of Internet, Information and Communication Systems, 1(1), 001-012. 
ALA. (1989). Presidential committee on information literacy. Retrieved January 16, 2021, from https://web.archive.org/web/20111201065026/http://www.ala.org/ala/mgrps/divs/acrl/ publications/whitepapers/presidential.cfm.

Andrews, C. R., \& Saint Hilaire, D. (2017). Aligning the Curriculums for College Success: High School and College Library Collaborations. Community \& Junior College Libraries, 23(1-2), 41-62. Doi: 10.1080/02763915.2018.1558900

Badke, W . (2010). Foundations of information literacy: Learning from Paul Zurkowski. Online, 34(1), 48-50.

Bent, M., \& Stubbings, R. (2011). The SCONUL Seven Pillars of Information Literacy: Core Model. Dostupné z: https://eprints.ncl.ac.uk/file_store/production/192828/5958D66D-1875-41A68B3F-C839D63BE398.pdf

Brown, K. B., \& Malenfant, K. J. (2017). Academic library impact on student learning and success: Findings from assessment in action team projects. Association of College and Research Libraries.

Burns, E., Gross, M., \& Latham, D. (2019). The information literacy continuum: Mapping the ACRL framework to the AASL school library standards. School libraries worldwide, 25(1), 1-20.

Camiling, M. K. S. (2019). eHealth Literacy of High School Students in the Philippines. IAFOR Journal of Education, 7(2), 69-87. Doi: 10.22492/ije.7.2.04

Candy, P. C. (2002). Lifelong learning and information literacy. Retrieved October, 20, 2004.

Candy, P. C. (2004). Linking thinking: Self-directed learning in the digital age. Canberra, Australia: Department of Education, Science and Training.

Carr, J. A., \& Rockman, I. F. (2003). Information-literacy collaboration: A shared responsibility. American Libraries, 34(8), 52-54.

Catalano, A. J. (2010). Using ACRL standards to assess the information literacy of graduate students in an education program. Evidence based library and information practice, 5(4), 21-38.

Černý, M. (2019). Pojetí informační gramotnosti v ŠVP: analýza kurikula tří vybraných středních škol. Journal Of Technology And Information Education, 11(2 ), 95-108. Doi: 10.5507/ jtie.2019.010.

ČŠI. Rozvoj informační gramotnosti na základních a středních školách ve školním roce 2016/2017 (2018 ed.). Retrieved January 16, 2021, from https://www.csicr.cz/ getattachment/09b94780-4fce-4acc-9fd1-178ab4c5eefd/TZ-Rozvoj-informacnigramotnosti-2016-2017.pdf.

Docherty, T. (2011). For the University: Democracy and the Future of the Institution. A\&C Black.

Dolničar, D., Podgornik, B. B., Bartol, T., \& Šorgo, A. (2020). Added value of secondary school education toward development of information literacy of adolescents. Library \& Information Science Research, 42(2), 101016.

Donham, J. (2014). College Ready--What Can We Learn from First-Year College Assignments? An Examination of Assignments in Iowa Colleges and Universities. School Library Research, 17.

Donham, J., \& Rehmke, D. (2016). High school to college transition: Sharing research with teachers. Teacher Librarian, 44(2), 13.

Duffy IV, M. J. (2019). What High School Students Want to Know about Music: An Information Literacy Instruction Course for a High School Music Camp. Music Reference Services Quarterly, 22(4), 171-188. Doi: 10.1080/10588167.2018.1558881

Dutton, W. H. (2004). Social transformation in an information society: Rethinking access to you and the world (Vol. 13). Paris: UNESCO.

Dzula, M., Wuu, S., Luna, J., Cook, A., \& Chen, S. (2020). Digital participation and risk contexts in journalism education. Media and Communication, 8(2), 219-231. Doi: 10.17645/mac.v8i2.2783 
Eisenberg, M. B., \& Berkowitz, R. E. (1999). Teaching Information \& Technology Skills: The Big6 [TM] in Elementary Schools. Professional Growth Series. Linworth Publishing, Inc., 480 East Wilson Bridge Rd., Suite L, Worthington, OH 43085.

Emmett, A., \& Emde, J. (2007). Assessing information literacy skills using the ACRL standards as a guide. Reference services review.

Farmer, L. \& Phamle, S. (2020). Transitioning to College: Impact of High School Librarians. In SITE Interactive Conference (pp. 430-439). Association for the Advancement of Computing in Education (AACE). Doi: 10.1016/j.acalib.2020.102262

Farmer, L. S. (2013). How AASL learning standards inform ACRL information literacy standards. Communications in Information Literacy, 7(2), 13.

Farmer, L. S. (2015). Information and digital literacies: A curricular guide for middle and high school librarians. Rowman \& Littlefield.

Fitzgerald, M. A. (2004). Making the leap from high school to college. Knowledge quest, 32(4), 19.

Foote, C. (2016). Building Success beyond High School with Career-and College-Ready Literacies. Knowledge Quest, 44(5), 56-60.

Gaha, U., Hinnefeld, S., \& Pellegrino, C. (2018). The academic library's contribution to student success: Library instruction and GPA. College \& Research Libraries, 79(6), 737.

Galvan, J. (2006). Writing literature reviews: A guide for student of the behavioral sciences. Glendale: Pyrczak Publishing.

Grizzle, A., Moore, P., Dezuanni, M., Asthana, S., Wilson, C., Banda, F., \& Onumah, C. (2014). Media and information literacy: policy and strategy guidelines. Unesco.

Hani Syazillah, N., Kiran, K., \& Chowdhury, G. (2018). Adaptation, translation, and validation of information literacy assessment instrument. Journal of the association for information science and technology, 69(8), 996-1006. Doi: 10.1002/asi.24023

Hart, C. (2005). Doing a literature review: Releasing the social science research imagination. London: Sage.

Head, A. (2013). Learning the ropes: How freshmen conduct course research once they enter college. Available at SSRN 2364080.

Herb, U. (2010). Sociological implications of scientific publishing: Open access, science, society, democracy and the digital divide.

Hughes, H., Cooper, L., Flierl, M., Somerville, M. M., \& Chaudhary, N. (2018). The role of the university library in supporting international student transition: Insights from an AustralianAmerican case study. The journal of academic librarianship, 44(5), 582-594. Doi: 10.1016/j. acalib.2018.06.003

Cheek, J., \& Doskatsch, I . (1998). Information literacy: a resource for nurses as lifelong learners. Nurse Education Today, 18(3), 243-250.

Jarvis, P. (2007). Globalization, lifelong learning and the learning society: Sociological perspectives. Routledge.

Jarvis, P. (Ed.). (2009). The Routledge international handbook of lifelong learning. Routledge.

Johnson, H. A., \& Barrett, L. (2017). Your teaching strategy matters: how engagement impacts application in health information literacy instruction. Journal of the Medical Library Association: JMLA, 105(1), 44. Doi: 10.5195/jmla.2017.8

Kyllönen, M. (2019). A New Narrative for the Future: Learning, Social Cohesion and Redefining "Us". In Sustainability, Human Well-Being, and the Future of Education (pp. 311-338). Palgrave Macmillan.

Lanning, S., \& Mallek, J. (2017). Factors influencing information literacy competency of college students. The Journal of Academic Librarianship, 43(5), 443-450. 
Llorente, H. J. G., Abad, F. M., \& Conde, M. J. R. (2019, March). Validación de un instrumento de evaluación de competencias informacionales autopercibidas en educación secundaria obligatoria. In Anales de Documentación (Vol. 22, No. 1). Facultad de Comunicación y Documentación y Servicio de Publicaciones de la Universidad de Murcia. Doi: 10.6018/ analesdoc.22.1.305641

Lwehabura, M. J. (2018). An assessment of information literacy skills among first-year postgraduate students at Sokoine University of Agriculture Tanzania. Journal of Librarianship and Information Science, 50(4), 427-434.

Mareš, J. (2013). Přehledové studie: jejich typologie, funkce a způsob vytváření. Pedagogická orientace, 23(4), 427-454.

Maunder, R. E., Cunliffe, M., Galvin, J., Mjali, S., \& Rogers, J. (2013). Listening to student voices: Student researchers exploring undergraduate experiences of university transition. Higher education, 66(2), 139-152.

Mayer, P. (2009). Guidelines for writing a review article. Zurich-Basel: Plant Science Center. Dostupné z http://www.plantscience.ethz.ch/education/Masters/courses/Scienti6ic_Writing

Mendez, I. M., Pories, M. L., Cordova, L., Malki, A., Wiggins, M. F., \& Lee, J. G. (2019). A pilot project to increase health literacy among youth from seasonal farmworker families in rural eastern North Carolina: a qualitative exploration of implementation and impact. Journal of the Medical Library Association: JMLA, 107(2), 179. Doi: 10.5195/jmla.2019.560

Moeller, S., Joseph, A., Lau, J., \& Carbo, T. (2011, November). Towards media and information literacy indicators. In Background document of the UNESCO Expert Meeting (Bangkok, Thailand, 4-6 November 2010).

Moto, S., Ratanaolarn, T., Tuntiwongwanich, S., \& Pimdee, P. (2018). A Thai Junior High School Students' 21 st Century Information Literacy, Media Literacy, and ICT Literacy Skills Factor Analysis. International Journal of Emerging Technologies in Learning, 13(9). Doi: 10.3991/ijet. v13i09.8355

Nath, H. K. (2017). The information society. NATH, Hiranya. The Information Society. Space and Culture, India, 4, 19-28.

Needleman, I. G. (2002). A guide to systematic reviews. Journal of clinical periodontology, 29, 6-9.

Ngo, H. T., Pickard, A. J., \& Walton, G. (2019). Information literacy capabilities of upper secondary students: the case of Vietnam. Global Knowledge, Memory and Communication. Doi: 10.1108/ GKMC-03-2019-0037

Ngo, H. T., Pickard, A. J., \& Walton, G. (2019a). An information literacy teaching model for Vietnam's schools. Global Knowledge, Memory and Communication. Doi: 10.1108/GKMC-052018-0047

Nishikawa, T., \& Izuta, G. (2019). The Information Technology Literacy Level of Newly Enrolled Female College Students in Japan. Humanities \& Social Sciences Reviews, 7(1), 01-10. Doi: 10.18510/hssr.2019.711

North, D. C., Wallis, J. J., \& Weingast, B. R. (2009). Violence and the rise of open-access orders. Journal of democracy, 20(1), 55-68.

Nzomo, P., \& Fehrmann, P. (2020). Advocacy engagement: The role of information literacy skills. Journal of Information Literacy, 14(1). Doi: 10.11645/14.1.2695

Oyediran-Tidings, S. O., Ondari-Okemwa, E. M., \& Nekhwevha, F. H. (2019). Information needs and constraints of access to educational information in the Fort Beaufort Education District. South African Journal of Education, 39(1). Doi: 10.15700/saje.v39ns2a1652

Pashkova-Balkenhol, T., Lenker, M., Cox, E., \& Kocevar-Weidinger, E. (2019). Should we flip the script: A literature review of deficit-based perspectives on first-year undergraduate students' information literacy. Journal of Information Literacy, 13(2). Doi: 10.11645/13.2.2619 
Randolph, J. J. (2009). A guide to writing the dissertation literature review. Practical Assessment, Research and Evaluation, 14(13), 1-13. Dostupné z http://pareonline.net/getvn. asp? $\mathrm{v}=14 \& \mathrm{n}=13$.

Ribot, J. C., \& Peluso, N. L. (2003). A theory of access. Rural sociology, 68(2), 153-181.

Rozas, L. W., \& Klein, W. C. (2010). The value and purpose of the traditional qualitative literature review. Journal of Evidence-Based Social Work, 7(5), 387-399.

Salisbury, F., \& Karasmanis, S. (2011). Are they ready? Exploring student information literacy skills in the transition from secondary to tertiary education. Australian Academic \& Research Libraries, 42(1), 43-58.

Saunders, L. (2017). Connecting information literacy and social justice: Why and how. Communications in Information Literacy, 11(1), 15.

Şenyurt, Ö., \& Önal, H. İ. (2019). Türk millî eğitim sisteminde bilgi okuryazarlığı: Politikalar, öğretim programları, öğretmenler ve öğrenciler üzerine bir araştırma. Bilgi Dünyası, 20(1), 25-63. Doi: 10.15612/BD.2019.730

Schofield, C. K. (2012). An examination of the information literacy expectations and practices of librarians in Connecticut state colleges and universities and Connecticut public high schools (Doctoral dissertation, University of Bridgeport).

Soysal, F., Coşkun, E., \& Alma, B. (2017, April). Proposal of a Framework for the Assessment of ICT Literacy and Examining the Structure of High School Students' ICT Literacy: A Case of Turkey. In International Conference on Computer Supported Education (Vol. 2, pp. 276-283). SCITEPRESS. Doi: 10.5220/0006272202760283

Svirina, N. S. (2020). Modern libraries practices for teaching information literacy. Bibliosphere, (4), 46-53. Doi: 10.31862/2309-1428-2020-8-1-164-177

Turusheva, L. (2009). Students' information competence and its importance for life-long education. Problems of Education in the 21st Century, 12, 126.

Udofia, U. I. (2012). Information needs of rural secondary school adolescents in Nigeria. International Journal of Academic Research in Business and Social Sciences, 2(10), 296.

Uzunboylu, H., \& Hürsen, Ç. (2011). Lifelong learning competence scale (LLLCS): The study of validity and reliability. Hacettepe Üniversitesi Ĕ̈itim Fakültesi Dergisi, 41(41), 449-460.

Vitori, V., Sulić, P., \& Bakmaz, M. (2018). Program Informacijsko opismenjavanje tinejdžera Gradske knjižnice Zadar. Vjesnik bibliotekara Hrvatske, 61(1), 127-150. Doi: 10.30754/ vbh.61.1.655

Webber, S., \& Johnston, B. (2017). Information literacy: Conceptions, context and the formation of a discipline. Journal of Information Literacy, 11(1).

Yoshida, M. (2018). An Investigation of the Social Network System Competencies of High School Students in Japan. International Journal of Emerging Technologies in Learning, 13(5). Doi: 10.3991/ijet.v13i05.8101

Zurkowski, P. G. (1974). The Information Service Environment Relationships and Priorities. Related Paper No. 5. Retrieved November 25, 2020, from https://files.eric.ed.gov/fulltext/ ED100391.pdf. 